\title{
AN OVERVIEW OF PROSES CNC MACHINING
}

\author{
Agrisa, Herick Henci ${ }^{1,2}$ \\ ${ }^{1}$ Work Safety Department, Dwi Aneka Teknik Ltd., South Sumatera, Indonesia \\ ${ }^{2}$ Mechanical Engineering Department, Sriwijaya University, South Sumatera, Indonesia
}

\begin{abstract}
This paper discusses the pre and process of running a computer numerical control machine (CNC) using computer-aided design (CAD) software commonly used to design products to be produced and computer-aided manufacture (CAM) software used to control machines during the manufacturing process. Some types of CNC machines in general, namely $\mathrm{CNC}$ lathe machine and CNC milling machine. The history of the development of the CNC Machine was begun in 1952 by John Pearseon of the Massachusetts Institute of Technology on behalf of the United States Air Force, which aims to make complicated special workpieces. In addition, this paper also discusses the basic numerical code types used in $\mathrm{CNC}$ machines.
\end{abstract}

Keywords: CNC, Machining, CAM, CAD

\section{INTRODUCTION}

Mechanical engineering students must know the basic knowledge of computer numerical control (CNC). Before running a $\mathrm{CNC}$ machine, students must first launch the object to be carried out using Computer-based software[1]. Computer aided design (CAD) and computer aided manufacturing (CAM) are now connected to each other in one software. This integration is needed for improving the quality of design, increasing engineer productivity, and improving communication between designers and readers. In addition, the models that we have designed can also contain features such as mass, volume, material strength, temperature, etc. [2].

The CAM is computer software to control machine tools during the manufacturing process. The CAM is a continuation of the computer aided design (CAD) and computer aided engineering (CAE) processes. The uses of software in the manufacturing industry can reduce the production of waste and the energy used is relatively small, increased speed, efficiency, product consistency, and more detailed accuracy.

Progress in manufacturing industry technology in the Industrial 4.0 era has increased very rapidly. The progress made now is that software on a computer can be used for the machining process, which includes grinding, lathe, surface milling, and welding. Collaboration between computer and mechanical technology creates CNC machines. The goal of Industry 4.0 is to work with higher levels of automation that achieve higher levels of income and efficiency[3], [4], connecting physically to the virtual world [5], [6].

Actually the work steps using a $\mathrm{CNC}$ machine are almost the same as manufacturing machines in general. However, there is additional control from the computer in regulating the movement of the machine. The working system of the use of the CNC machine tool itself is to synchronize the relationship between the computer and its mechanical devices. Along with technological developments in manufacturing, manual machining processes have begun to be replaced by automated machining processes because largescale industries demand production speed and precision of production. in modern times, many industries in developed countries have abandoned equipment that uses conventional machinery and switched to computer numerical control machine tools.

The CNC machines require a computer aided design (CAD) software program. The CNC machines will answer the challenges going forward in the manufacturing industry because the large numbers of products can be done with the same results and comprehensive processing time. This CNC machine can be applied in all fields

*Corresponding author's email: herikagrisa@ gmail.com 
such as industry, education and health in order to produce results that are beneficial to everyone and can be used in daily life.

\section{PROCESS MANUFACTURE}

On many types of $\mathrm{CNC}$ machines, how to operate it is enough to enter numerical commands via the buttons that are indeed provided for data input. Lathes have many specifications such as center lathe, vertical turning and boring milling, facing lathe, turret lathe, etc. The CAD-CAM software is used to design the dimensions to be produced and then the image is changed to G-code. These are the steps for a $\mathrm{CNC}$ machine can produce products according to design, namely:

\subsection{CAD/CAM}

Before using a CNC machine program, a basic understanding and knowledge of technical drawing design must first have. Technical drawings can be created manually or using CAD software. If used CAD software, a program of technical drawings that have been designed can display, where this program can be directly operated on CNC machines. The CNC machines are usually connected to the CAM application program to make optimal machine performance. There are two CAD software that is often used to design: SOLIDWorks and CAMWorks.

SOLIDWorks is one of the most common software used by engineers to design and simulate which is basically a 2D and 3D graphics application that focuses on device development. SOLIDWorks software itself is one of the reliable software support for technological advances in various industries, such as Automotive, Engineering, Medicine and others[2]. The cover of SOLIDWORKS software for 2018 version can be seen in Figure 1.

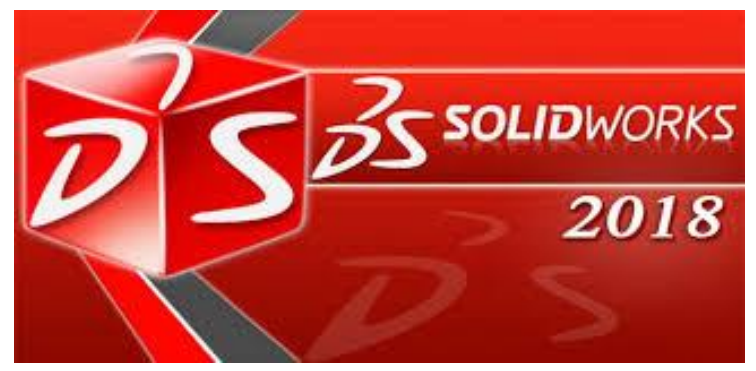

Figure 1 SOLIDWorks 2018 Edition [7]

The next is CAMWorks software. The CAMWorks software is software that bridges the work of CAD connected to CAM that makes it easy for operators because it can be used in programs that are truly effective in the correction process and easy to use supported formats [2]. The cover of CAMWorks 2018 version can be seen in Figure

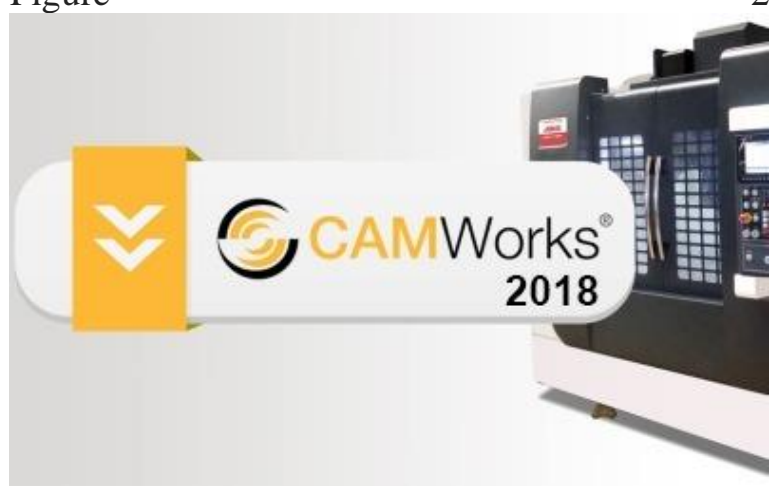

Figure 2 CAMWorks 2018 Edition [8]

Working drawings for $\mathrm{CNC}$ machine work processes on a personal computer (PC) can be designed using CAM software. After the design is made then it is executed into a simulation to see the execution of the workpiece carried out by the $\mathrm{CNC}$ machine. If the workpiece has an error or is lacking can immediately repair it without losing the material or data used previously. If the simulation results as desired, the CNC machine program is then prepared to be executed. Through a network or cable that is transferred through the recording media, the $\mathrm{CNC}$ machine program will be connected directly.

Another role of simulation is as a vehicle for the presentation of the system and makes it easier to present it to others. The ability of simulations is a further step in advancing this role. Based on this, behavior of the system can be display using a portable microcomputer [9].

\subsection{CNC Machining}

The CNC program is then sent and executed by the processor to the $\mathrm{CNC}$ so as to produce servo motor settings on the CNC Machine to drive the Tool in carrying out the Work process that produces products that are in accordance with the Program. On a scale from Medium to Large industries, CNC machines have many uses to support the production process. In general, $\mathrm{CNC}$ machines have 2 types as follows:

\section{CNC Lathe machine}

$\mathrm{CNC}$ lathe has the basic movement principle as a conventional lathe, namely the movement in the direction of transverse and horizontal with $\mathrm{X}$ axis and $\mathrm{Z}$ axis coordinate systems [10]. The working principle of $\mathrm{CNC}$ lathe is also the 
same as the conventional lathe. Figure 3 is isometrics view of CNC Lathe Machine.

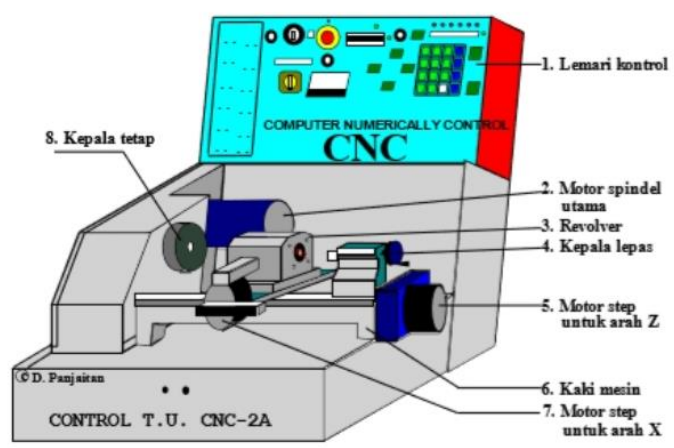

Figure 3 CNC Lathe Machine [11]

2. CNC Milling machine.

CNC milling machines consist of machine tool parts and $\mathrm{CNC}$ control parts. Machine tools consist of cutting and gripping parts, milling machine tables, and workpiece grip holders. This machine can be used with Cartesian coordinate systems and polar coordinate systems. The coordinate system will describe the machine's movement as relative to the cutting tool with the workpiece. This coordinate system is a coordinate system with three axes namely the $\mathrm{X}$ axis, $\mathrm{Y}$ axis, and $\mathrm{Z}$ axis [12]. Figure 4 is isometric view of $\mathrm{CNC}$ Milling Machine.

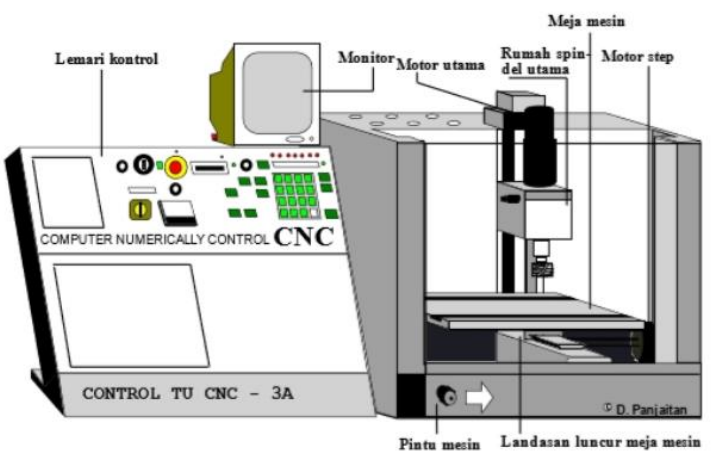

Figure 4 CNC Milling Machine [13]

There are several steps that must be done in the CNC machining process (see Figure 5)[1]:

1. Plan and draw the workpiece using CAD software;

2. Process the image into numeric code or $\mathrm{G}$ code using CAM software;

3. Try to enter the numeric code into the software which is then simulated to see whether the system function as expected;

4. If the code does not experience a problem then it is followed by entering the workpiece parameters and their limitations into the $\mathrm{CNC}$ machine program;

5. Enter the numeric code / G-code that has been tested before and is ready to run to the CNC machine so that the workpiece process is in accordance with the previously designed design [1].

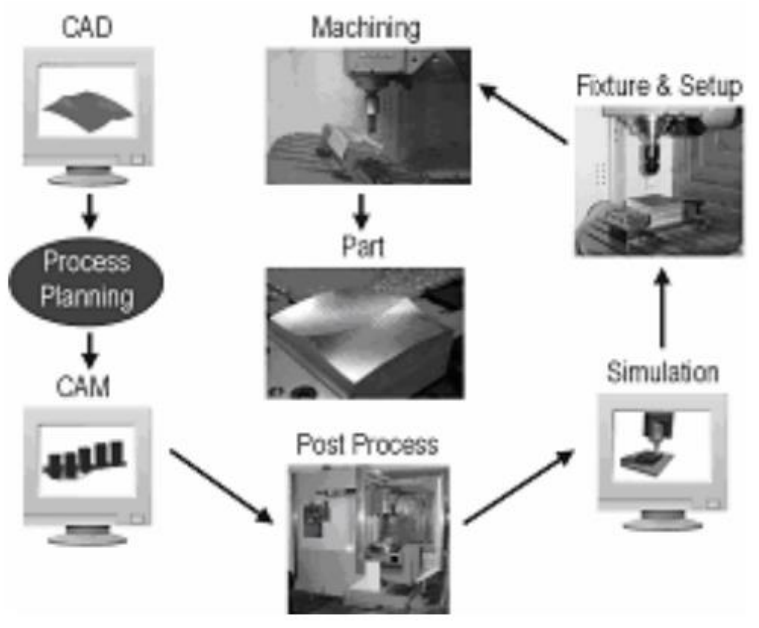

Figure 5 CNC machining process [14]

G-Code or numeric code is a function used in the numerical control programming language that contains information on the position of a tool to carry out a command. This G-code is an informal language that is commonly called colloquially but actually G-code is part of a numerical control programming language which aims to drive numerical control and CNC machines. Some examples basic code / numeric code (G-code) used in CNC machining [1]:

G90: Absolute

G91: Incremental

G54-G9: Coordinate System

G00: Move axis position at full speed.

G01: Move axis positions linearly (feed rate).

X0, Y0 Z0: Starting point coordinates.

X Y Z: Coordinate direction of movement.

$F$ : Determine the speed of eating the workpiece

$\mathrm{S}$ : Determine the spindle rotation speed

M02: Spindle stop

M98: Enter to subprogram

M99: Exit to subprogram 
After the code is obtained then proceed by entering some parameters that have been adjusted so that the results obtained in accordance with the plan that has been designed previously.

The CNC machine will move according to the program that is entered into the computer so that the machine can be instructed to repeat the movement repeatedly with the same level of accuracy and dimensions [15].

\subsection{The advantage of using a CNC machine}

CNC lathes have many advantages compared to conventional lathes, namely[16]:

1. Production results can be controlled properly

2. Detailed and complex workmanship can be carried out automatically using

3. Operation and programming in accordance with needs

4. Manage the automation process only through special software.

5. The production time is very fast in large quantities with the exact same results.

\subsection{Development of CNC Machines}

The inception of the CNC (Computer Numerically Controlled) machine in 1952 was developed by John Pearseon of the Massachusetts Institute of Technology, on behalf of the United States Air Force, which aims to make complicated special workpieces. In 1973, CNC machines were still very expensive so there were only a few companies that had the courage to spearhead investment in this technology. From 1975, the production of CNC machines began to develop rapidly. This development was driven by the development of microprocessors, so the volume of the control unit can be more concise.[17]

The development of technological advances in the present is expected in the future because the input of CNC machines can come from manual work drawings that can be read through the scanner, then automatically interpreted by a PC connected to the CNC machine. The scanner reading results will then be processed by software using a PC in CAD-CAM format which can be simulated directly. Then, simulations that are in accordance with what is planned will be executed into the $\mathrm{CNC}$ machine program and ready to form objects according to the desired design [17].

\section{SUMMARY}

CNC machines are very influential in the development of the manufacturing industry because they can produce highly precise objects in large quantities. In order for $\mathrm{CNC}$ machine performance to run properly, $\mathrm{PC}$ has an important role to enter the program from the $\mathrm{CNC}$ machine. $\mathrm{CNC}$ machines require numeric codes or $\mathrm{G}$ codes to execute objects that were previously created using software recommended by CNC machine manufacturers. CNC machine manufacturers provide CAD-CAM design software that synergizes and is recommended for the $\mathrm{CNC}$ machines they produce.

\section{REFERENCES}

[1] E. Prianto and H. S. Pramono, "PROSES PERMESINAN CNC DALAM PEMBELAJARAN SIMULASI," pp. 62-68.

[2] Y. Setyoadi, K. Latifah, J. T. Mesin, and J. Informatika, "Integrasi Software CAD-CAM Dalam Sistem Operasi Mesin Bubut CNC," pp. 149-159.

[3] Y. Lu, N. Kaushal, N. Denier, and J. S. H. Wang, "Health of Newly Arrived Immigrants in Canada and the United States: Differential Selection on Health," Heal. Place, vol. 48, no. August, pp. 1-10, 2017, doi: 10.1016/j.healthplace.2017.08.011.

[4] M. Peruzzini, F. Grandi, and M. Pellicciari, "Benchmarking of Tools for User Experience Analysis in Industry 4.0," Procedia Manuf., vol. 11, no. June, pp. 806813, 2017, doi: 10.1016/j.promfg.2017.07.182.

[5] C. Leyh, S. Martin, and T. Schaffer, "Industry 4.0 and Lean Production-A Matching Relationship? An Analysis of Selected Industry 4.0 Models," Proc. 2017 Fed. Conf. Comput. Sci. Inf. Syst. FedCSIS 2017, vol. 11, pp. 989-993, 2017, doi: 10.15439/2017F365.

[6] F. Baena, A. Guarin, J. Mora, J. Sauza, and S. Retat, "Learning Factory: The Path to Industry 4.0," Procedia Manuf., vol. 9, pp. 73-80, 2017, doi: 10.1016/j.promfg.2017.04.022.

[7] "Solidworks." [Online]. Available: https://www.solidworks.com/. [Accessed: 07-Apr-2020]. 
[8] "CNC Softwere for Machine Tools." [Online]. Available: https://camworks.com/.

[9] J. Taiavage and D. Phillips, "Simulating Manufacturing Systems," no. May, pp. 53$55,1983$.

[10] "Pengetahuan Dasar Mesin Bubut Cnc." [Online]. Available: http://achmadarifin.com/pengetahuan-dasarmesin-bubut-cnc. [Accessed: 07-Apr-2020].

[11] "Mesin Bubut CNC," 2020. [Online]. Available: https://www.bukusekolah.net/. [Accessed: 18-Mar-2020].

[12] D. G. Subagio and T. D. Atmaja, "The Use of Open Source Software for Open Architecture System on CNC Milling Machine," J. Mechatronics, Electr. Power, Veh. Technol., vol. 2, no. 2, p. 105, 2012, doi: 10.14203/j.mev.2011.v2.105-112.
[13] "Mesin Frais CNC." [Online]. Available https://www.bukusekolah.net/2019/02/mesi n-frais-cnc.html. [Accessed: 18-Mar-2020].

[14] G. Poon, P. J. Gray, S. Bedi, and D. Miller, "Architecture for Direct Model-to-Part CNC Manufacturing," vol. 4, no. 1, pp. 14-18.

[15] Widarto, TEKNIK PEMESINAN JILID 2 SMK Direktorat Pembinaan Sekolah Menengah Kejuruan. 2010.

[16] S. Yoewono, W. Rojuli, and J. Ganesa, "PEMBUATAN PERANGKAT LUNAK CAM UNTUK MESIN CNC FREIS 3 SUMBU PADA AutoCAD," vol. XIX, no. 1, 2000.

[17] H. Seputro, D. T. Elektro, and F. T. Industri, "Mesin Cnc," pp. 1-7. 